\title{
CHK21100delC, I157T, IVS2 +IG > A, BRCA1 and BRCA2 Mutation Analysis in JF305: A Pancreatic Cancer Cell Line
}

\author{
Charles Ndawula Jr. ${ }^{1,2}$, Xueli Yang1, Xiaohai Gong1 ${ }^{1}$ Jian Jin ${ }^{1^{*}}$ \\ ${ }^{1}$ Laboratory of Molecular Pharmacology, School of Pharmaceutics, Jiangnan University, Wuxi, China \\ ${ }^{2}$ National Livestock Resources Research Institute, Tororo, Uganda \\ Email: ${ }^{*}$ Jinjian31@126.com
}

Received 10 February 2014; revised 11 March 2014; accepted 19 March 2014

Copyright (C) 2014 by authors and Scientific Research Publishing Inc.

This work is licensed under the Creative Commons Attribution International License (CC BY).

http://creativecommons.org/licenses/by/4.0/

C) (i) Open Access

\begin{abstract}
JF305 is a highly prolific pancreatic cancer cell line that originated from a Chinese patient. The cell line bears a functional HR double strand DNA repair mechanism but very responsive to PARP treatment a phenomenon clearly suggesting presence of an anomaly in the mechanism. Brca1, Brca2 and CHK2 proteins are very important constituents of the HR mechanism whose respective gene coding mutations are strongly associated with several cancers and are widely exploited in anticancer chemotherapy. In this current study, the BRCA1, BRCA2 gene mutation status in JF305 was determined together with the presence of 3 widely reported cancer linked CHK2 founder mutations (1100delC, I157T, IVS2 +IG > A). CHK21100delC genotype was determined using allele specific PCR, while the PCR-RFLP assay was used for I157T, IVS2 +IG > A analysis. PCR and direct sequencing were used for assessing the BRCA1 and BRCA2 gene. Results revealed that JF305 is CHK21100delC heterozygous mutant, CHK2I157T and CHK2IVS2 +IG > A wild type. Furthermore, it was observed that JF305 lacked BRCA1 and BRCA2 gene mutations. The mutation status identification of $\mathrm{CHK} 2$ and BRCA1/2 in JF305 provides a major milestone towards elucidating the properties of the cell line which subsequently promises to be an excellent model for evaluating the role of parp inhibitors in pancreatic cancer chemotherapy most especially in the respective cancer cell lines without BRCA1 and BRCA2 gene mutations.
\end{abstract}

\section{Keywords}

BRCA1; BRCA2; CHK21100delC; CHK2I157T; CHK2IVS2 +IG > A; Homologous Mechanism; PARP; Brca1; Brca2

\footnotetext{
"Corresponding author.
} 


\section{Introduction}

Genetic mutations are considered to be one of the major factors contributing to cancer although it is widely acknowledged that other factors such as environment, age, viral infections and smoking may be attributed to cancer incidences. There are an estimated 12.7 million cancer cases worldwide every year and this is expected to rise to 21 million by 2030 [1]. In China, 2.5 million cancer deaths are reported every year and 3.5 million new cancer cases reported every day [2]. Pancreatic cancer is reported to cause an estimated 213,000 death worldwide [3]. Not only is the overall pancreatic cancer prognosis poor, there is a less than 4\% 5-year patient survival rate [4] and resistance to many key chemotherapeutic agents and novel targeted therapies [5]. In search for potent parp inhibitors against cancer cell lines originating from China, current research work from our laboratory screened a panel of cells and identified JF305 to be highly sensitive to different low and high potent PARP inhibitors. JF305 is a pancreatic cancer cell line which was established in 1995 with a high proliferation rate of 2 3 days to reach confluence, a population doubling time of approximately 49.5 -h and plating efficiency of $30.6 \%$ [6]. PARP inhibitors are suggested to act by trapping PARP-1 and PARP-2 enzymes at the site of DNA damage forming parp-protein complexes that are toxic to cell [7]. They are also reported to act by inducing the accumulation of single stand breaks that become double strand breaks (DSBs) resulting in stalling of the replication forks causing cell death unless repaired. PAPR inhibition causes failure of the single stand DNA repair mechanism but does not have effect on the double strand DNA repair mechanism (DDR) [8].

Results from our preliminary studies showed RAD51 and $\gamma$-H2AXfoci formation a classical HR mechanism response during which $H 2 A X$ is only phosphorylated by ATM which is only activated during double stand DNA damage. This confirms that parp inhibitors induce double stand breaks (DSBs) triggering HR mechanism activation. JF305 therefore bears a functional HR mechanism which raises unanswered question on why JF305 seems to be sensitive to PARP inhibitors. Against this background, it would be ideal and reasonable to speculate that some constituents of the HR mechanism might contain genetic anomalies.

Ideally a cell maintains its genomic integrity and stability by accurately repairing damaged DNA such that no mutations are carried onto the daughter cells short of which may result in tumor progression. Brca 1 , Brca2 and Chk2 alongside RAD51, $\gamma$-H2AX, FANCN/PALB, Chk1 and ATM constitute the Homologous recombination repair mechanism [9] that functions together with MSH2, MLH1, MSH6, NBS1, MRE11, RAD50, BLM, and RFC multi protein complex in double stand DNA repair [10]. Mutations in any of the genes coding for proteins constituting the mechanism are likely to damage the HR functionality. However, BRCA1, BRCA2, ATM, and CHK2 genes are very instrumental in the repair mechanism. Together, mutations in BRCA1 and BRCA2 account for the majority of families with hereditary susceptibility to breast and ovarian cancer [11]-[13]. BRCA gene mutations may appear as heterozygous (one normal copy and one mutated copy) within the germ line. Epidemiologic studies have shown that BRCA1 mutation carriers have a high lifetime risk of breast cancer of up to $80 \%$ [14]. Similarly BRCA2 carriers are also at an increased risk for developing ovarian cancer as well as other solid tumors such as prostatic, pancreatic, gastric and colon cancers [15]. Breast cancer early onset 1/2 (BRCA1 and BRCA2) are human suppressor housekeeping genes that code for breast cancer susceptibility protein 1 and 2 (Brca1 and Brca2). BRCA1 and BRCA2 are located on chromosome 17 and 13 and each contains24 [16] and 27 exons [17]. Exon 11 represents 50\% and 60\% of the BRCA2 and BRCA1 entire genome [18]-[20] thus the largest. Most BRCA1 and BRCA2 mutations are located in exon 11 though also present in other exons therefore there is no particular hot spot. Although there is existence of several alternative strategies such as denaturing high performance liquid chromatography (DHPLC), single-strand conformation polymorphism (SSCP), denaturing gradient gel electrophoresis (DGGE), heteroduplex analysis (HA), fluorescent assisted mismatch analysis (FAMA) and the protein truncation test (PTT), direct DNA sequencing (DS) remains the gold standard for detecting BRCA mutations [21].

CHK2 also known as CHEK2 is a versatile multifunctional cell cycle check point kinases that amplifies the cells' response to DNA damage by phosphorylating a number of downstream cellular substrates like Brca1, PML, E2F1, P53, CDC25A, CDC25C [22]. CHK2 is located on chromosome 22q12.1 [23] comprising of 3 distinct domains; the SQ/TQ cluster domain (SCD), Fork-head associated domain (FHA) and the Serine/Threonine kinase domain [22]-[24]. SCD domain is an N-terminal domain that contains the Ser/Gln/Thr-Gln classical site for ATM phosphorylation with Thr68 as the primary target site [22] [24]. The FHA is a centrally located domain that binds to the phosphorylated Thr68 SCD segments [24]. Serine/Threonine kinase domain is located at C terminal and only active during DNA damage [24]. Three founder mutations 1100delC, I157T, and 1422delT were 
first identified in Li-Fraumeni syndrome patients [25] but 1422delT is a polymorphism in a non-processed Psuedogene [26]. Other CHK2 mutations like S428F, IVS2 +IG > 2 and 5395delC have also been reported in different studies [27]-[30]. CHK2110delC is characterized by deletion of a single cystein at position 1100 located just at the beginning of exon 10 in the serine/threonine kinase domain and resulting in a frame shift mutation and an introduction of a stop codon after the 380 amino acid [25]. It is also regarded as a low penetrance breast cancer susceptible gene evident in individuals without BRCA1 and BRCA2 mutations [31]. CHK2IVS2 $+\mathrm{IG}>\mathrm{A}$ mutation involves a $\mathrm{G}>\mathrm{A}$ substitution in exon 2 splice site of the FHA domain resulting in a frame shift mutation and formation of a premature termination codon in exon 3 [32] [33]. And the I157T involves Thymine Cytosine misense mutation at the second position of codon 157 in exon FHA domain resulting in Isoleucine Threonine substitution [32]. CHK2 is considered as a multi-organ cancer susceptibility gene contributing to the development of numerous cancers; including breast, colorectal, prostate, ovarian, thyroid and kidney cancers [34]. Both truncating and missense CHK2 gene mutations lower the kinase activity in response to DNA damage [35] and confer an increased cancer risk [22]. Screening of most germ line mutations in DNA is conducted using PCR and direct sequencing method. However, reports from CHK2 germ line mutations analysis indicated that the genome exhibits high homology to exons 10 and 14 making mutation analysis problematic [36]. Long-range PCR may be used to overcome the problem; however, the allele specific PCR and RFLP methods are widely used to screen for particular established CHK2 mutations.

From the available literature, it is evident that limited or no research work has been undertaken to evaluate the BRCA 1, BRCA2 and CHK2 mutation status in JF305. The objective of this current research work was therefore to evaluate the BRCA1, BRCA2, CHK21100delC, I157T, and IVS2 +IG > A mutation status in JF305.

\section{Materials and Methods}

The JF305 was purchased from Wuxi BioHermesInc and cultured in RPMI 1640 supplemented with 10\% FBSmaintained at $37^{\circ} \mathrm{C}$ and $5 \% \mathrm{CO}_{2}$.

\subsection{DNA and mRNA Isolation}

Prior to DNA or RNA extraction, JF305 cells were cultured to confluence but the cells cultured for mRNA extraction were supplemented with $100 \mu \mathrm{g} / \mathrm{mL}$ cycloheximide for at least 6 hours. Genomic DNA and mRNA were extracted using the General AllGen kit (Cwbiotech cat cw2298) and the mRNA Isolation kit (Roche cat 11741985). Extracted mRNA was then transcribed into cDNA using the TaKaRa Reverse Transcriptase MMLV (RNase H-) kit (cat No. 2641). All kits were used according to the manufacturers' instructions and samples stored at $-20^{\circ} \mathrm{C}$.

\subsection{CHK21100delC Mutation Analysis}

CHK21100delC mutation genotyping and zygosity were determined using the allele specific PCR method as previously described [37]. Two sets of reaction mixtures were prepared both containing a common forward primer Chk210F 5'-GCAAAGACATGAATCTGTAAAGTC-3', a different allele specific reverse primer; Chk210 WildR: 5'-AAATCTTGGAGTGCCCAAAATCAG 3 (specific for wild type allele), Chk210mutR:

5'-AAATCTTGGAGTGCCCAAAATAAT-3'(specific for mutant allele), the SLC30A9F:

5'GTCAAAGCCACCAGTTACAGT-3' and SLC30A9R: 5'-TTCCCCACCACTTACTGAC-3' primers targeting exon 8 solute carrier family 30 member 9 (SLC30A9) gene as the internal control. Wild type allele specific PCR amplification was performed using the following conditions; $95^{\circ} \mathrm{C}$ for 5 minutes, $\left[95^{\circ} \mathrm{C}\right.$ for 20 seconds, $60^{\circ} \mathrm{C}$ for 20 seconds $72^{\circ} \mathrm{C}$ for 20 seconds] 40 cycles and final extension $72^{\circ} \mathrm{C}$ for 5 minutes [38]. Mutant allele specific PCR amplification conditions were; $94^{\circ} \mathrm{C}$ for 3 minutes, $\left[94^{\circ} \mathrm{C}\right.$ for 30 seconds, $50^{\circ} \mathrm{C}$ for 30 seconds, $70^{\circ} \mathrm{C}$ for 30 seconds] 35 cycles and final extension $72^{\circ} \mathrm{C}$ for 7 minutes. All PCR products were separated using $2 \%$ agarose gold view stained gel and visualized under UV light.

To determine the zygosity, successfully amplified products were subsequently analyzed using the same common forward primer, altering the allele specific reverse primer and maintaining the same internal control gene specific primers. PCR reactions were performed using a C100 touch thermal cycler in a $20 \mu \mathrm{L}$ reaction mixture containing $1 \times$ Taq master mix (CWBIO cat cw0582), $250 \mathrm{ng}$ genomic DNA, $0.2 \mu \mathrm{M}$ forward and reverse primers. 


\subsection{CHK2I157T Mutation Analysis}

CHK2I157T genotyping was determined using PCR-RFLP as previously described [39]. The 155bp region prone to the Thymine-Cytosine mutation (amino acid 430) was amplified using specific primers Chk2157F: 5'-ACCCATGTATCTAGGAGAGCTG-3' and Chk2157R: 5'-CCACTGTGATCTTCTATGTCTGCA-3'. The PCR was conducted in a $20 \mu \mathrm{L}$ reaction mixture containing $1 \times$ Taq master mix (CWBIO cat cw0582), 250 ng genomic DNA, $0.2 \mu \mathrm{M}$ forward and reverse primers using a $\mathrm{C} 100$ touch thermal cycler. The following PCR conditions were used; $94^{\circ} \mathrm{C}$ for $3 \mathrm{~min},\left[94^{\circ} \mathrm{C} 30 \mathrm{~s}, 56^{\circ} \mathrm{C}\right.$ for $40 \mathrm{~s}, 72^{\circ} \mathrm{C}$ for $40 \mathrm{~s}$ ] 30 cycles final extension $72^{\circ} \mathrm{C}$ for $5 \mathrm{~min}$ [38]. The amplified PCR products were separated using $2 \%$ agarose gold view stained gel and visualized under UV light. Subsequently, they were digested overnight using 5 units of PstI (New England Biolabs) restriction enzyme, targeting the site introduced by the reverse primer in case of Thymine-Cytosine mutation and the digestion was confirmed using agarose electrophoresis.

\subsection{CHK2IVS2 +IG > A Mutation Analysis}

We amplified the $491 \mathrm{G}>$ A residual fragment mutation site using the PCR-RFLP assay as previously described [41] using Chk2IVSF: 5'-ATTTATGAGCAATTTTTAAACG-3' and Chk2IVSR: 5'-

TCCAGTAACCATAAGATAATAATATTAC-3' primers. The PCR constituted of a $20 \mu \mathrm{L}$ reaction mixture containing $1 \times$ Taq master mix (CWBIO cat cw0582), $250 \mathrm{ng}$ genomic DNA, $0.2 \mu \mathrm{M}$ forward and reverse primers. Amplification was conducted at $95^{\circ} \mathrm{C}$ for $5 \mathrm{~min},\left[94^{\circ} \mathrm{C}\right.$ for $60 \mathrm{~s}, 53^{\circ} \mathrm{C}$ for $60 \mathrm{~s}, 72^{\circ} \mathrm{C}$ for $\left.60 \mathrm{~s}\right] 35 \mathrm{cycles}$ and a final extension at $72^{\circ} \mathrm{C}$ for $7 \mathrm{~min}$ [38] using a $\mathrm{C} 100$ touch thermal cycler. The amplified products were confirmed using $2 \%$ gold view stained gel and then digested over night at $37^{\circ} \mathrm{C}$ using 5 units of Hpy $188 \mathrm{III}$ (New England Biolabs) restriction enzyme.

\subsection{BRCA1/2 Gene Amplification}

BRCA 1 and BRCA2 genes were amplified using a series of primers (Table 1) overlapping the entire gene segments (Figures 1(a) and (b)). Amplification of exon 11 in both genes was conducted using genomic DNA template while cDNA template was used for all other segments. We used a $20 \mu \mathrm{LPCR}$ reaction volume composed of $1 \mathrm{U}$ prime stare max DNA polymerase (TaKaRabioinccat $\neq \mathrm{R} 045 \mathrm{aA}), 250$ ng genomic or cDNA, $0.2 \mu \mathrm{M}$ reverse and forward primers. All PCR reaction were conducted at $98^{\circ} \mathrm{C}$ for $1 \mathrm{~min},\left[98^{\circ} \mathrm{C} 10 \mathrm{~s}\right.$, varying annealing temperatures (Table 1) $72^{\circ} \mathrm{C}$ for $\left.25 \mathrm{~s}\right] 35$ cycles and final extension $72^{\circ} \mathrm{C}$ for 5 min using aC100 touch thermal cycler. All amplified products were separated using a $1 \%$ gold view stained gel, visualized under UV light, purified and submitted to Sangon Biotech (Shanghai) Co Ltd for sequencing. The generated sequences were assembled and analyzed using DNAMAN 5.0 software.

\section{Results}

\subsection{CHK2 Mutation Analysis}

CHK21100delC wild type and Mutant allele specific PCR gel analysis indicated the presence of 309, 184 and 309, 183 bp bands (Figures 2(a) and 3(a)). Subsequent wild and mutant type CHK21100delCzygosity allele specific PCR gel analysis also indicated the presence of 309, 183 and 309, 184 bp bands (Figures 2(b) and 3(b)). The presence of $309 \mathrm{bp}$ band confirms the amplification of the SLC30A9 gene used as the internal control while the 184 and 183bp products indicates presence of wild and mutant alleles. Zyogisty allele specific PCR clearly demonstrated that JF305 carries a heterozygous CHK21100delC mutation. CHK2110delcPCR-RFLP analysis also indicated the presence of the mutation in question (data not shown). The positive CHK21100delC mutant samples were sequenced and the generated data was aligned against CHK2 gene bank sequencies (NCBI Reference Sequence: NG_008150.1).

CHK2I157T and CHK2IVS2 +IG > A PCR-RFLP analysis showed amplification of a 155 and 491 bp products which persisted after the restriction digestion reaction (Figures 4 and 5).

Absence of the 136 and 19 bp bands after the PstI restriction digestion reaction of CHK2I157TPCR products indicates that there was no Threonine Isoleucine substitution a consequence of thymine cytosine misense mutation at 157 position [32] hence no formation of PstI restriction site. The persistence of a 155 bp band after RFLP reveals that JF305 lacks the CHK2I15T mutation. Similarly the absence of 297 and 197 bp bands after Hpy188III 
Table 1. BRCA1/2 primers, the respective product sizes and annealing temperatures with all forward primers $(\mathrm{F})$ containing a T7 promoter: ggatcctaatacgactcactataggaacagaccaccatg and translational start codon underlined. All BRCA1 and BRCA2 segments correspond to gene access number U14680.1 and U43746.1.

\begin{tabular}{|c|c|c|c|c|c|}
\hline No & Exon BRCA1 & Primer sequence 5 '-3' & Temperature $\left({ }^{\circ} \mathrm{C}\right)$ & Product size bp & Source \\
\hline 1 & $2-10:$ & $\begin{array}{l}\text { F1: gatttatctgctcttcgcgt }(123-142) \\
\text { R1:gttggggaggcttgecttct }(1538-1519)\end{array}$ & 55 & 1454 & [39] \\
\hline 2 & 11 & $\begin{array}{l}\text { F2: gctgcttgtgaatttctgag }(789-809) \\
\text { R2: gcctgcagtgatattaactgtctg }(2903-2880)\end{array}$ & 55 & 1591 & [40] \\
\hline 3 & 11 & $\begin{array}{l}\text { F3: agcagaatggtcaagtgatgaat (1854-1873) } \\
\text { R3: GCCCACTTCATTAGTACTG (3397-3379) }\end{array}$ & 50 & 1681 & {$[40]$} \\
\hline 4 & 11 & $\begin{array}{l}\text { F4: tcatctcagttcagaggcaa }(2982-3001 \\
\text { R4: agtttgaatccatgctttgc }(4212-4193)\end{array}$ & 55 & 1268 & [40] \\
\hline 5 & $12-24$ & $\begin{array}{l}\text { F5: gaagtagttcagactgttaa }(3462-3481) \\
\text { R6: tcagtagtggctgtgggggatc }(5711-5690)\end{array}$ & 55 & 2287 & [39] \\
\hline 6 & BRCA2 1-10 & $\begin{array}{l}\text { F6: cctattggatccaaagaga }(232-250) \\
\text { R6: ggttcttcagaatcattctgtg }(2192-2171)\end{array}$ & 55 & 1998 & \\
\hline 7 & 11 & $\begin{array}{l}\text { F7: ggtttattgcattcttctgtg }(2137-2157) \\
\text { R8: ttctttaatctgagtgtttc }(4374-4355)\end{array}$ & 47.9 & 1837 & {$[20]$} \\
\hline 8 & 11 & $\begin{array}{l}\text { F9: cattcttctgtgaaaagaagctg }(2146-2168) \\
\text { R9: tggtttgaattaaaatcctgc }(3530-3510)\end{array}$ & 55 & 1422 & [40] \\
\hline 9 & 11 & $\begin{array}{l}\text { F10:ccaagctacatattgcagaag }(3625-3645) \\
\text { R10: ctcgttgtttccttaatta }(5865-58460)\end{array}$ & 50 & 2378 & {$[20]$} \\
\hline 10 & 11 & $\begin{array}{l}\text { F11: gatcagaaaccagaagaattgc }(4579-4600) \\
\text { R11: ttgggatattaaatgttctggagta }(6354-6330)\end{array}$ & 55 & 1813 & [40] \\
\hline 11 & $12-18$ & $\begin{array}{l}\text { F12accaggcaagtctttccaaa }(6247-6268) \\
\text { R12: agatgatgtcttctccatcc }(8736-8717)\end{array}$ & 55 & 2527 & [20] \\
\hline 12 & $19-27$ & $\begin{array}{l}\text { F13: gattatacatatttcgcaatgaaag }(8738-8762) \\
\text { R13:ggtttgaaattatattccag }(10560-10541)\end{array}$ & 55 & 1860 & \\
\hline
\end{tabular}

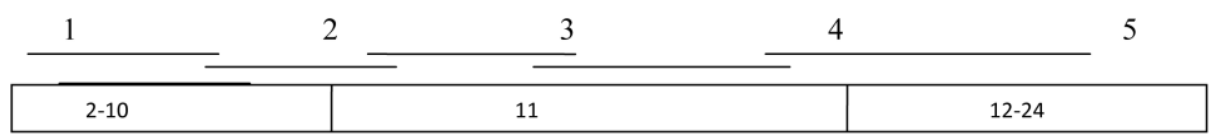

(a)

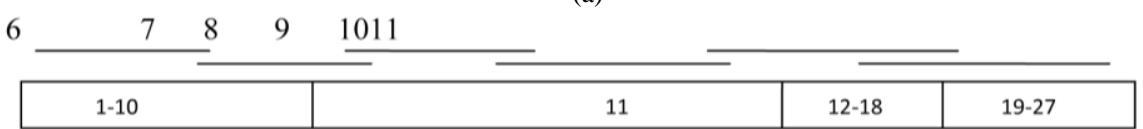

(b)

Figure 1. (a) Diagrammatic representation of BRCA1 coding sequences indicating the overlapping segments that were amplified using the primer sequences indicated in Table 1; (b) Diagrammatic representation of BRCA2 coding sequences indicating the overlapping segments that were amplified using the primer sequences indicated in Table 1.

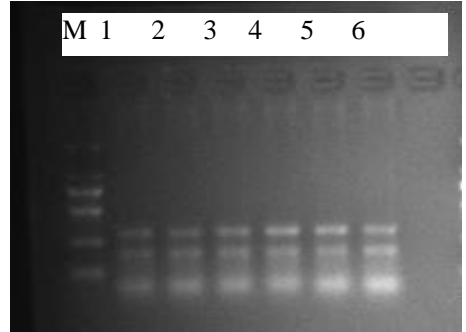

(a)

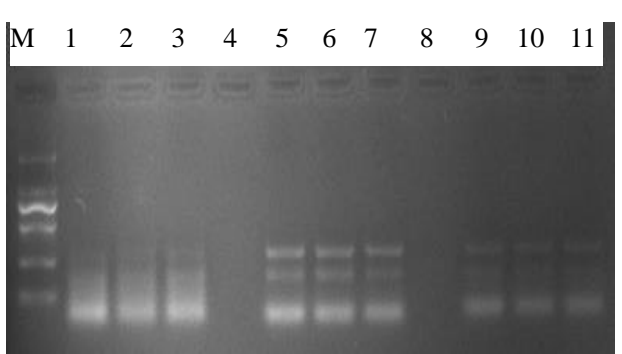

(b)

Figure 2. CHK21100delC mutation allele specific PCR. M; DM2000 DNA marker, (2a) Lanes 1 - 6 are 309 and 183 bp PCR bands obtained using mutation specific, common forward, SLC30A9 forward and reverse primers showing the presence of mutant allele and. (2b) Lanes 5 - 7 and 9 - 11 are 184 and 309 bp bands obtained from the subsequent PCR reaction using wild type specific, common forward, SLC30A9 forward and reverse primers showing the presence of wild type allele and SLC30A9 internal control gene. Summary; CHK21100delC heterozygous mutation confirmed present in JF305. (a) Mut AS-PCR; (b) Mut Zygosity AS-PCR. 


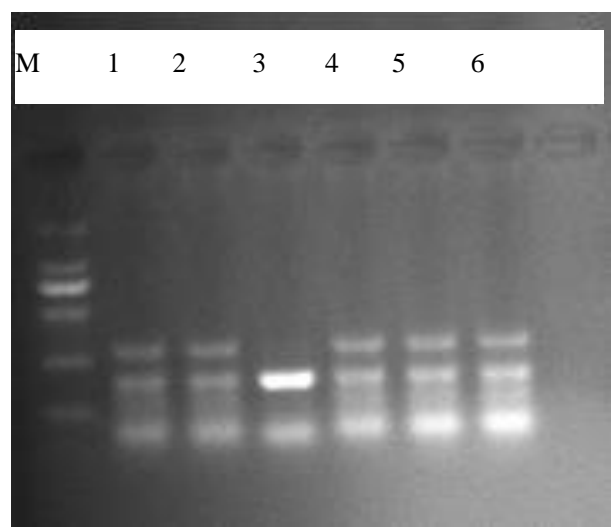

(a)

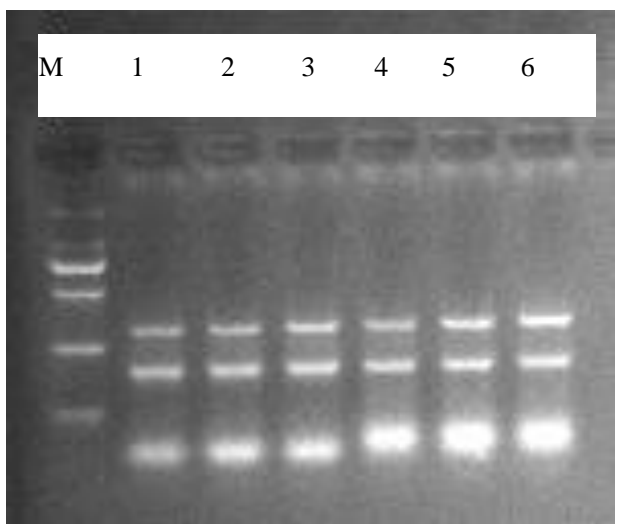

(b)

Figure 3. CHK21100delC wild allele specific PCR. M; DM2000 DNA marker, (3a) Lanes 1 - 6 are 309 and $184 \mathrm{bp}$ bands obtained using wild type specific, common forward, SLC30A9 forward and reverse primers showing the presence of mutant allele and. (3b) Lanes $1-6$ are 183 and 309 bp products from subsequent PCR reaction obtained using mutation allele specific, common forward, SLC30A9 forward and reverse primers showing the presence of mutant allele and SLC30A9 internal control gene. Summary; CHK21100delC heterozygous mutation confirmed present in JF305. (a) Wild AS-PCR; (b) Wild zygosity AS-PCR.



I157T PCR RFLP

Figure 4. Gel captions of CHK2 mutation analysis; Lanes 1 - 3 and 4 - 6 are 155 bp PCR and RFLP products indicating successful amplification and no PstI restriction digestion. CHK2I157T mutation confirmed absent in JF305.

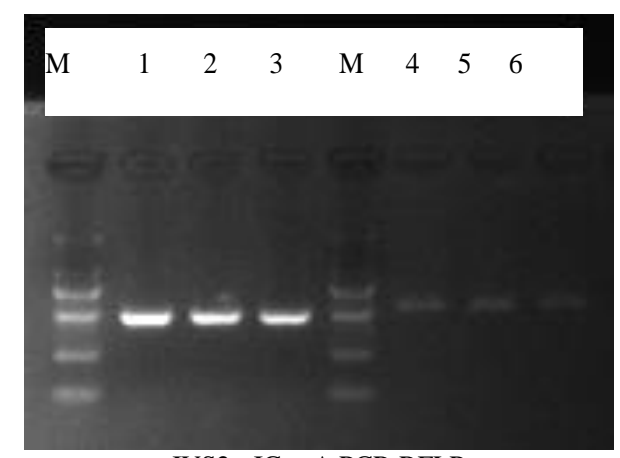

IVS2 +IG > A PCR RFLP

Figure 5. Lanes $1-3$ and $4-6$ are 491 bp PCR bands and RFLP products indicating successful amplification and no Hpy188III restriction digestion. CHK2IVS2 +IG > A mutation confirmed absent in JF305. 


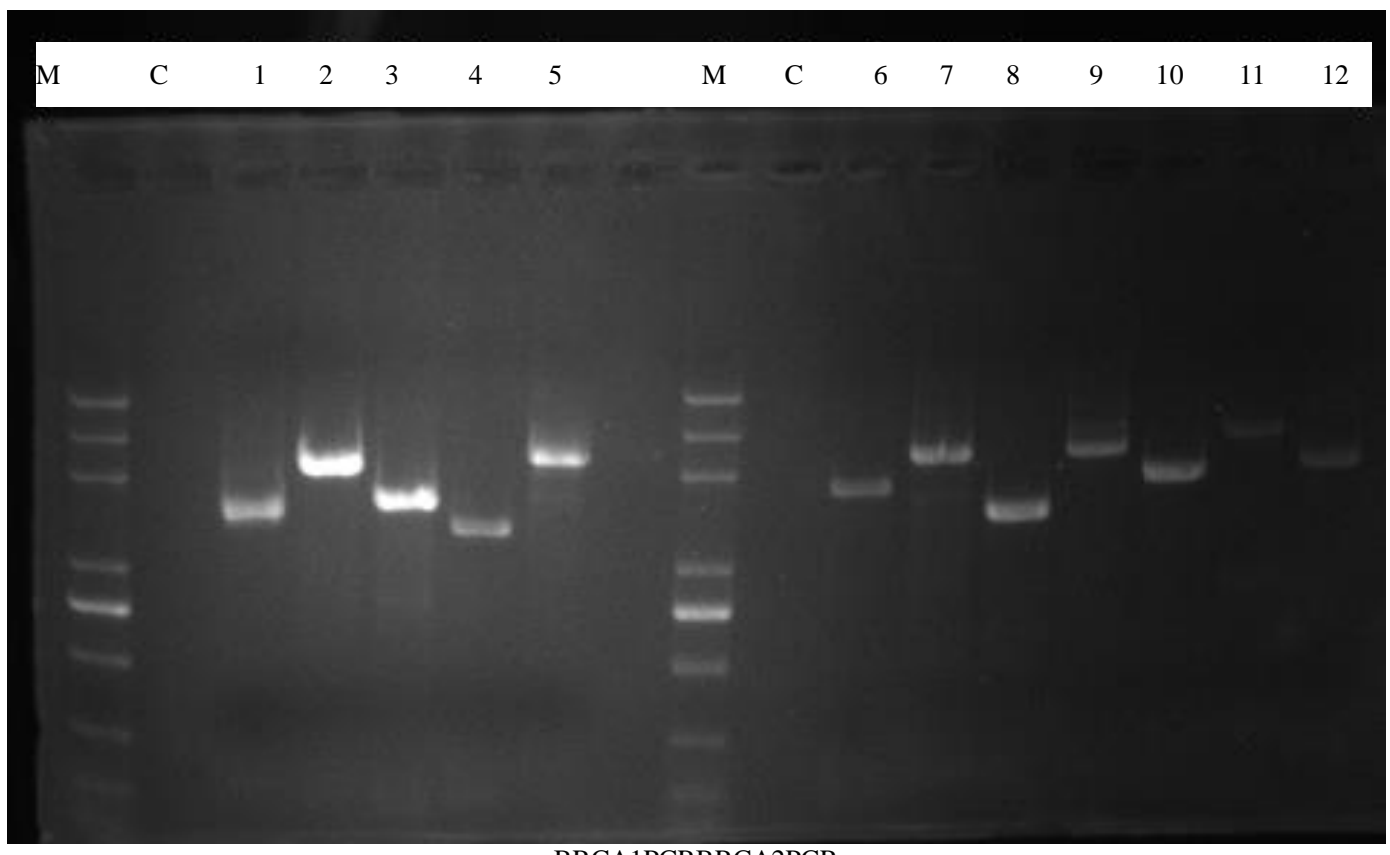

BRCA1PCRBRCA2PCR

Figure 6. Gel caption of BRCA1 and BRCA2PCR amplification: M; DM2000plus marker, C; negative control, lanes 1 - 5 and 6 - 12 are respective BRCA1 and BRCA2PCR products obtained using primers stated in Table 1.

restriction digestion indicated the absence of the corresponding restriction site which is due to lack of $\mathrm{G}>\mathrm{A}$ substitution [32]. The persistence of 491 bp band confirms that JF305 lacks IVS2 +IG > A mutation.

\subsection{BRCA1 and BRCA 2 Analysis}

PCR gel electrophoresis analysis showed the amplification of different BRCA1 and BRCA2 segments (Figure 6) Alignment of generated gene sequences against U14680.1 and U43746.1 confirmed the absence of BRCA1 and BRCA2 mutations. This clearly indicated that JF305 is proficient in both BRCA1 and BRCA1and lack mutations.

\section{Discussions}

The BRCA gene was analyzed and three reported CHK2 were characterized in this study. Furthermore, we demonstrated that JF305 carries a CHK21100delC mutation one of the two mutations identified in Li-Fraumeni syndrome patients and no BRCA1 or BRCA2 mutations (26). This phenomenon is yet to be reported in JF305 and other pancreatic cancer cell lines but has been widely associated with increased risk of breast cancer. CHK21100delC confers low penetrance susceptibility to breast cancer in non carriers of BRCA1 and BRCA2 [31]. CHK21100delC is classified by nucleotide deletion and frame shift at $\mathrm{C}$ terminal kinase domain resulting in loss of kinase activity compromising the downstream targets of activated CHK2. Findings from our preliminary studies revealed impaired expression of phosphoryatedCHK2 and reduced expression levels of total CHK2 (data not shown) which also strongly indicates the presence of CHK2 mutation [35].

On the other hand BRCA is the most extensively studied gene due to its significance in increased risk for cancer. In an effort to improve on the accuracy, both BRCA1 and BRCA2 gene amplification is obtained using a nested pcr (2 sets of primers) [20] [39] [40]. However in this study, we successfully amplified both BRCA genes using a single set of primers and prime star DNA polymerase. This approach simplifies BRCA gene amplification making the process quick and less costly. Since the pcr products also contain the T7 promoter, they may directly be applied in the protein truncation test (PTT) for further analysis.

The findings in this studyhave demonstrated that the CHK21100delC confers low penetrance susceptibility to pancreatic cancer in non carriers of BRCA1 and BRCA2 mutations. There is need for further epidemiological 
evaluation considering that this phenomenon has only been unraveled in JF305 unlike other pancreatic cancer cell lines.

\section{Conclusion}

Our study findings have shown that JF305 is CHK21100delC heterozygous mutant, CHK2I157T and CHK2IVS2 $+\mathrm{IG}>\mathrm{A}$ wild type. Our findings have also revealed that JF305 lacks BRCA1 and BRCA2 gene mutations. It can therefore be concluded that the mutation status establishment of CHK2 and BRCA1/2 in JF305 provides a major milestone towards elucidating the properties of the cell line which subsequently promises to be an excellent model for evaluating the role of parp inhibitors in pancreatic cancer chemotherapy most especially in the respective cancer cell lines without BRCA1 and BRCA2 gene mutations.

\section{Acknowledgments}

The authors gratefully acknowledge the support for this research work by China National Science Grant and hereby declare no conflict of interest in regards to this work.

We are also indebted to Dr. Amadou Issoufou for his input in manuscript editing and to Livestock Resources Research Institute for their support in this research undertaking and for accepting the first author undertook his postgraduate training in China.

\section{References}

[1] Fund WCR. http://wwwwcrf-ukorg/research/cancer statistics/world cancer statistics

[2] China's Cancer Crisis. http://wwwchinaorgen/2013-04/16/content_28556502htm

[3] Parkin, D.M., Bray, F., Ferlay, J. and Pisani, P. (2001) Estimating the World Cancer Burden: Globocan 2000. International Journal of Cancer, 94, 153-156. http://dx.doi.org/10.1002/ijc.1440

[4] Jemal, A., Siegel, R., Xu, J. and Ward, E. (2010) Cancer Statistics. A Cancer Journal for Clinicians, 60, $277-300$. http://dx.doi.org/10.3322/caac.20073

[5] Matthaios, D., Zarogoulidis, P., Balgouranidou, I., Chatzaki, E. and Kakolyris, S. (2011) Molecular Pathogenesis of Pancreatic Cancer and Clinical Perspectives. Oncology, 81, 259-272. http://dx.doi.org/10.1159/000334449

[6] Li, X., Wang, H. and Jiang, Y. (1995) Establishment of a Human Pancreatic Adenocarcinoma Cell Line (Jf305) with p53 Expression. Chinese Journal of Cancer Research, 7, 251-254. http://dx.doi.org/10.1007/BF02672786

[7] Murai, J., Huang, S.Y., Dar, B.B., Renaud, A., Zhang, Y., Doroshow, J.H., Ji, J., Takeda, S. and Pommier, Y. (2012) Trapping of PAPR1 and PARP2 by Clinical Parp Inhibitors. Cancer Research, 72, 5588-5599. http://dx.doi.org/10.1158/0008-5472.CAN-12-2753

[8] Georges, N., Nicole, G.I., Marie, F., Frederique, M.C. and Vicent, F. (2003) Poly (ADP-Ribose) Polymerase (Parp-1) Is Not Involved in DNA Double Strand Break Recovery. BMC Cell Biology, 4, 7. http://dx.doi.org/10.1186/1471-2121-4-7

[9] Wang, X.Z. and Weaver, D.T. (2011) The Ups and Downs of DNA Repair Biomarkers for PARP Inhibitor Therapies. American Journal of Cancer Research, 1, 301-327.

[10] Henderson, B.R. (2012) The BRCA1 Breast Cancer Suppressor: Regulation of Transport, Dynamics, and Function at Multiple Subcellular Locations. Scientifica, Article ID 796808. http://dx.doi.org/10.6064/2012/796808

[11] Hall, J.M, Lee, M.K., Newman, B., Morrow, J.E., Anderson, L.A., Huey, B. and King, M.C. (1990) Linkage of EarlyOnset Familial Breast Cancer to Chromosome 17q21. Science, 250, 1684-1689. http://dx.doi.org/10.1126/science.2270482

[12] Hofmann, W. and Schlag, P.M. (2000) BRCA1 and BRCA2 - Breast Cancer Susceptibility Genes. Journal of Cancer Research and Clinical Oncology, 126, 487-496. http://dx.doi.org/10.1007/s004320000140

[13] Carter, R.F. (2001) BRCA1, BRCA2 and Breast Cancer: A Concise Clinical Review. Clinical Investigation Medicine, 24, 147-157.

[14] Satagopan, J.M., Offit, K., Foulkes, W., Robson, M.E., Wacholder, S., Eng, C.M., Karp, S.E. and Begg, C.B. (2001) The Lifetime Risks of Breast Cancer in Ashkenazi Jewish Carriers of BRCA1 and BRCA2 Mutations. Cancer EpideMiology, Biomarkers \&Prevention, 10, 467-473.

[15] Peto, J., Collins, N., Barfoot, R., Seal, S., Warren, W., Rahman, N., Easton, D.F., Evans. C., Deacon, J. and Stratton, M.R. (1999) Prevalence of BRCA1 and BRCA2 Gene Mutations in Patients with Early-Onset Breast Cancer. Journal of National Cancer Institute, 91, 943-949. http://dx.doi.org/10.1093/jnci/91.11.943 
[16] http://www.ncbi.nlm.nih.gov/nuccore/U14680.1

[17] http://www.ncbi.nlm.nih.gov/nuccore/U43746.1

[18] Smith, T.M., Szabo, L.M., Jerome, C. I., McEuen, N., Taylor, M., Hood, M.L. and King, M.C. (1996) Complete Genomic Sequence and Analysis of $117 \mathrm{~kb}$ of Human DNA Containing the Gene BRCA1. Genome Research, 6, 1029 1049. http://dx.doi.org/10.1101/gr.6.11.1029

[19] Wooster, R., Neuhausen,S.L., Mangion, J., Quirk, Y., Ford, D., Collins, N., Nguyen, K., Seal, S., Tran, T., Averill, D., et al. (1994) Localization of a Breast Cancer Susceptibility Gene, BRCA2, to Chromosome 13q12-13. Science, 265, 2088-2090. http://dx.doi.org/10.1126/science.8091231

[20] Garvin, A.M., Attenhofer-Haner, M. and Scott, R.J. (1997) BRCA1 and BRCA2 Mutation Analysis in 86 Early Onset Breast/Ovarian Cancer Patients. Journal of Medical Genetics, 34, 990-995. http://dx.doi.org/10.1136/jmg.34.12.990

[21] Christine, S., Jean-Paul, M., Claire, J.R., François, E., Dominique, S.L., Brigitte, B.P. and Hagay, S. (2002) Testing for BRCA1 Mutations: A Cost-Effectiveness Analysis. European Journal of Human Genetics, 10, 599-606. http://dx.doi.org/10.1038/sj.ejhg.5200854

[22] Antoni, L., Sodha, N., Collins, I. and Garrett, M.D. (2007) CHK2 Kinase: Cancer Susceptibility and Cancer TherapyTwo Sides of the Same Coin? Nature Review Cancer, 7, 925-936. http://dx.doi.org/10.1038/nrc2251

[23] Bayram, S., Akkız, H. and Topaktaş, M. (2013) CHK2 1100delC, IVS2+1G>A and I157T Mutations Are Not Present in Hepatocellular Cancer Cases from a Turkish Population. Gene, 512, 232-236. http://dx.doi.org/10.1016/j.gene.2012.10.045

[24] Ahn, J., Urist, M. and Prives, C. (2004) The Chk2 Protein Kinase. DNA Repair (Amst.), 3, 1039-1047. http://dx.doi.org/10.1016/j.dnarep.2004.03.033

[25] Bell, D.W., Varley, J.M., Szydlo, T.E., Kang, D.H., Wahrer, D.C., Shannon, K.E., Lubratovich, M.S., Verselis, J., Isselbacher, K.J., Fraumeni, J.F., Birch, J.M., Li, F.P., Garber, J.E. and Haber, D.A. (1999) Heterozygous Germ Line hCHK2 Mutations in Li-Fraumeni Syndrome. Science, 286, 2528-2531. http://dx.doi.org/10.1126/science.286.5449.2528

[26] Sodha, N., Williams, R., Mangion, J., Bullock, S.L., Yuille, M.R. and Eeles, R.A. (2000) Screening hCHK2 for Mutations. Science, 289, 359.

[27] Shaag, A., Walsh, T., Renbaum, P., Kirchhoff, T., Nafa, K., Shiovitz, S., Mandell, J.B., Welcsh, P., Lee, M.K., Ellis, N., Offit, K., Levy-Lahad, E. and King, M.C. (2005) Functional and Genomic Approaches Reveal an Ancient CHEK2 Allele Associated with Breast Cancer in the Ashkenazi Jewish Population. Human Molecular Genetics, 14, 555-563. http://dx.doi.org/10.1093/hmg/ddi052

[28] Cybulski, C., Gorski, B., Huzarski, T., Masojc, B., Mierzejewski, M., Dębniak, T., et al. (2004) CHEK2 Is a Multiorgan Cancer Susceptibility Gene. The American Journal of Human Genetics, 75, 1131-1135. http://dx.doi.org/10.1086/426403

[29] Cybulski, C., Huzarski, T., Górski, B., Masojć, B., Mierzejewski, M., Debniak, T., Gliniewicz, B., Matyjasik, J., Złowocka, E., Kurzawski, G., Sikorski, A., Posmyk, M., Szwiec, M., Czajka, R., Narod, S.A. and Lubiński, J. (2004) A Novel Founder CHEK2 Mutation Is Associated with Increased Prostate Cancer Risk. Cancer Research, 64, $2677-2679$. http://dx.doi.org/10.1158/0008-5472.CAN-04-0341

[30] Cybulski, C., Wokołorczyk, D., Huzarski, T., Byrski, T., Gronwald, J., Górski, B., Debniak, T., Masojć, B., Jakubowska, A., Gliniewicz, B., Sikorski, A., Stawicka, M., Godlewski, D., Kwias, Z., Antczak, A., Krajka, K., Lauer, W., Sosnowski, M., Sikorska-Radek, P., Bar, B., Klijer, R., Zdrojowy, R., Małkiewicz, B., Borkowski, A., Borkowski, T., Szwiec, M., Narod, S.A. and Lubiński, J. (2006) A Large Germline Deletion in the Chek2 Kinase Gene Is Associated with an Increased Risk of Prostate Cancer. Journal of Medical Genetics, 43, 863-866. http://dx.doi.org/10.1136/jmg.2006.044974

[31] Meijers-Heijboer, H., Van den, A., Klijn, M., Wasielewski, J., de Snoo., A., Oldenburg, R., Hollestelle, A., Houben, M., Crepin, E., van Veghel-Plandsoen, M., Elstrodt, F., van Duijn, C., Bartels, C., Meijers, C., Schutte, M., McGuffog, L., Thompson, D., Easton, D., Sodha, N., Seal, S., Barfoot, R., Mangion, J., Chang-Claude, J., Eccles, D., Eeles, R., Evans, D.G., Houlston, R., Murday, V., Narod, S., Peretz, T., Peto, J., Phelan, C., Zhang, H.X., Szabo, C., Devilee, P., Goldgar, D., Futreal, P.A., Nathanson, K.L., Weber, B., Rahman, N. and Stratton, M.R. (2002) Low-Penetrance Susceptibility to Breast Cancer Due to CHEK2(*)1100delC in Noncarriers of BRCA1 or BRCA2 Mutations. Nature Genetics, 31, 55-59. http://dx.doi.org/10.1038/ng879

[32] Dong, X.Y., Wang, L., Ken, T., Wang, X.S., Julie, M., Cunningham, M., McDonnell, S.K., Chiping, Q., Angela, F., Marks, S., Susan, L.S., Peterson, B.J., Smith, D.I., Cheville, J.C., Blute, M.L., Jacobsen, S.J., Schaid, D.J., Tindall, D.J., Thibodeau, S.N. and Liu, W. (2003) Mutations in CHEK2 Associated with Prostate Cancer Risk. The American Journal of Human Genetics, 72, 270-280. http://dx.doi.org/10.1086/346094

[33] Kleibl, Z., Havranek, O., Novotny, J., Kleiblova, P., Soucek, P. and Pohlreich, P. (2008) Analysis of CHEK2 FHA 
Domain in Czech Patients with Sporadic Breast Cancer Revealed Distinct Rare Genetic Alterations. Breast Cancer Research and Treatment, 112, 159-164. http://dx.doi.org/10.1007/s10549-007-9838-7

[34] Cybulski, C., Górski, B., Huzarski, T., Masojć, B., Mierzejewski, M., Dębniak, T., Teodorczyk, U., Byrski, T., Gronwald, J., Matyjasik, J., Złowocka, E., Lenner, M., Grabowska, E., Nej, K., Castaneda, J., Mędrek, K., Szymańska, A., Szymańska, J., Kurzawski, G., Suchy, J., Oszurek, O., Witek, A., Narod, S.A. and Lubiński, J. (2004) CHEK2 Is a Multiorgan Cancer Susceptibility Gene. The American Journal of Human Genetics, 75, 1131-1135. http://dx.doi.org/10.1086/426403

[35] Matsuoka, S., Nakagawa, T., Masuda, A., Haruki, N., Elledge, S.J. and Takahashi, T. (2001) Reduced Expression and Impaired Kinase Activity of a Chk2 Mutant Identified in Human Lung Cancer. Cancer Research, 61, 5362-5365.

[36] Sodha, N., Richard, S.H., Richard, W., Martin, A.Y., John, M. and Rosalind, A.E. (2002) A Robust Method for Detecting CHK2/RAD53 Mutations in Genomic DNA. Humanmutation, 19, 173-177. http://dx.doi.org/10.1002/humu.10031

[37] Djureinovic, T., Lindblom, A., Dalén, J., Dedorson, S., Edler, D., Hjern, F., Holm, J., Lenander, C., Lindforss, U., Lundqvist, N., Olivecrona, H., Olsson, L., Påhlman, L., Rutegård, J., Smedh, K., Törnqvist, A., Eiberg, H. and Bisgaard, M.L. (2006) The CHEK2 1100delC Variant in Swedish Colorectal Cancer. Anticancer Research, 26, 48854888 .

[38] Bayram, S., Akkız, H. and Topaktaş, M. (2013) CHK2 1100delC, IVS2+1G>A and I157T Mutations Are Not Present in Hepatocellular Cancer Cases from a Turkish Population. Gene, 512, 232-236. http://dx.doi.org/10.1016/j.gene.2012.10.045

[39] Garvin, A.M. (1998) A Complete Protein Truncation Test for BRCA1 and BRCA2. European Journal of Human Genetics, 6, 226-234. http://dx.doi.org/10.1038/sj.ejhg.5200172

[40] Ottini, L., D’Amico, C., Noviello, C., Lauro, S., Lalle, M., Fornarini, G., Colantuoni, O.A., Pizzi, C., Cortesi, E., Carlini, S., Guadagni, F., Bianco, A.R., Frati, L., Contegiacomo, A. and Mariani-Costantini, R. (2000) BRCA1 and BRCA2 Mutations in Central and Southern Italian Patients. Breast Cancer Reserch, 22, 307-310. http://dx.doi.org/10.1186/bcr72

[41] Cybulski, C., Górski, B., Huzarski, T., Masojć, B., Mierzejewski, M., Dębniak, T., Teodorczyk, U., Byrski, T., Gronwald, J., Matyjasik, J., Złowocka, E., Lenner, M., Grabowska, E., Nej, K., Castaneda, J., Mędrek, K., Szymańska, A., Szymańska, J., Kurzawski, G., Suchy, J., Oszurek, O., Witek, A., Narod, S.A. and Lubiński, J. ( 2004) CHEK2 Is a Multiorgan Cancer Susceptibility Gene. The American Journal of Human Genetics, 75, 1131-1135.

http://dx.doi.org/10.1086/426403 